\title{
OPTIMISATION OF SELECTION IN AEROBIC GYMNASTICS BY CORRELATING PHYSICAL AND TECHNICAL ELEMENTS
}

\author{
Mariana MEZEI ${ }^{1 *}$, Teodora WESSELLY ${ }^{1}$, Raluca Anca PELIN', \\ Carmen GRIGOROIU ${ }^{1}$ \\ 1 "Politehnica" University, Department of Physical Education and Sport - Kinetotherapy, Bucharest, Romania
*Corresponding author: mariana_apostu@yahoo.com
}

DOI: 10.35189/iphm.icpesk.2019.20

\begin{abstract}
Achieving top performance in aerobic gymnastics is determined by the perfect acquisition of technical elements and a superior level of motor skills. In this study, we aimed to analyse and compare the difficulty elements imposed by the technical requirements for juniors in performance aerobic gymnastics with the training level of the investigated athletes by applying specific motor tests. The selection of the applied tests seeks to provide a complex picture of the motor/physical requirements for practicing this sports discipline. Athletes were asked to perform the movement in conditions of support, hanging, static and dynamic strength, dynamic balance, but also space and time orientation. The research was conducted between 20 July and 30 July 2018 on a group of 18 gymnasts (14 girls and 4 boys) aged 14 years, with a competitive experience of 5 to 6 years. The testing took place in the gym of the National Sports Centre in Deva. The analysis of motor qualities in relation to the achievement of the assessed technical elements has provided a new perspective for the coaches in order to build the new junior team. Promoting talented athletes will lead to the validation of the proposed goals, but also to achieving long-term performance.
\end{abstract}

Keywords: aerobic gymnastics, selection, juniors, motor tests.

\section{Introduction}

Derived from the family of gymnastic sports, aerobic gymnastics has become more and more popular in recent years due to its spectacular character, the increased difficulty of the elements, the increased artistic level of the compositions and the rigorous structuring of the training patterns.

Although quite newly emerged, the Romanian aerobic gymnastics school has shaped its own distinct profile, gaining international attention since 1995, when, at the first World Championship, the Romanian gymnasts won the silver medal in the trio event, but also the third place by nation. From then until today, Romanian technicians have been constantly concerned with introducing performance criteria into the training content, according to the Code of Points that has been regularly updated.

The development of this sport worldwide has also occurred due to the increase in the number of children and junior athletes, which is a favourable prerequisite for enhancing the selection base in aerobic gymnastics. Currently, Romanian coaches are focused on identifying talented children, under the conditions of a decreased selection base compared to other countries and previous periods.

Scientific contributions highlight descriptive aspects of the technique by identifying spatial and temporal factors (Seirul-Io Vargas, 1987) of the technical elements viewed in an integrative perspective. Specifically, the movement analysis and analytical interpretation should take into account the dynamic factors involving muscular support, the informational factors referring to the gymnast's ability to self-adjust their own actions and the psychological aspects facilitating the use of the learned technique (Bota \& Urzeală, 2013). Rieder (1987) confirms that technical execution equally involves elements relating to motor completion (physical aspects) and cognitiveaffective aspects. Raiola, Giugno, Scassillo and Di Tore (2013) introduce performance analysis by video images and notational analysis for a more objective examination of technical movements.

Authors like Lijuan (2013) or Xiao-Ying and Huang (2008) analyse the tendency of difficulty elements according to the FIG consecutive Code of Points.

In addition to technical aspects, physical preparation must support the high difficulty and complexity of movements, being one of the top priorities for coaches. Sergiev (2004) emphasises that motor qualities/physical abilities are supposed to develop differently during various preparation stages; moreover, he identifies three types of physical abilities related to the performance of difficulty elements, movement patterns and the full routine.

The study of the literature, as well as our long coaching experience, led us to identify the necessary motor skills without which difficulty elements cannot be achieved:

- Explosive power in the upper and lower body required for vertical jump; 
- Strength in the abdominal and back muscles required to propel the body into the air and maintain the static and dynamic elements;

- Plyometric strength in the arms, shoulder girdle and lower limbs required in the landing and shockabsorbing phase;

- Coordination abilities that condition the work of the arms and lower limbs, as well as spatial orientation required to perform elements of rotation around the longitudinal and horizontal axis;

- Flexibility in the limb joints required for balance and some jumping elements.

Related to physical abilities, several studies focus on developing valid, reliable and sensitive field-specific tests designed to assess anaerobic physical performance in acrobatic gymnasts (Alves et al., 2015).

Another topic relates to the investigation of aerobic fitness and physiological and energy responses during competitive exercises (Aleksandraviciene, Zaicenkoviene, Stasiule, \& Stasiulis, 2015). This approach is meant to accurately objectify the physiological demands of the events in this branch of sport.

\section{Problem statement}

In 2018, a group of juniors was established with the purpose of increasing their technical, physical and artistic potential for a successful transition to senior category. This approach specifically involves:

- improving the four technical elements imposed by the Code of Points for junior category - Straddle support, Straddle jump, Illusion to vertical split, Helicopter to wenson;

- strengthening physical abilities through the standardisation of physical preparation in accordance with the technical execution requirements.

This approach makes it possible to correctly learn technical elements and prevent typical execution errors (caused by inappropriate physical preparation), as well as to minimise the traumatic risk often associated with poor physical support and a state of fatigue.

\section{Research questions}

How can selection, as a continuous process, be improved in order to correctly predict the increase in the gymnast's potential required for a successful transition to senior category?

What correlations are there between the four mandatory elements of difficulty for junior category and the tests assessing strength and mobility qualities?

\section{Research purpose}

This study aims to provide a statistical argument for some tests investigating the physical preparation of athletes, which technicians consider to be defining for the technical execution of the four difficulty elements imposed by the Code of Points for junior category. This is useful, on the one hand, to create age-group scales for physical preparation and, on the other hand, to achieve a standardisation of physical preparation starting from the biomechanical and physiological demands of each technical element.

\section{Material and Methods}

\section{Research subjects and location}

The study included 18 junior athletes certified by the Romanian Gymnastics Federation, belonging to several sports clubs across the country. Subjects are aged 14 years and have over 5 years of competitive experience.

The research was carried out between 20 and 30 July 2018 (during the National Youth Camp) at the National Sports Centre in Deva.

The tests were conducted as part of the national selection procedure for the junior team and consisted in assessing the execution of technical elements by grades from 1 to 10, taking into account all requirements specified in the Code of Points. At the same time, strength and mobility qualities were measured with the help of nine tests; thus, three of them were evaluated by grades, and six were assessed quantitatively. All subjects in the tested group agreed to participate in this study after being informed about its purpose. In this regard, their informed consent was obtained.

All subjects were clinically healthy, and the environment where the study took place provided optimum conditions to conduct the research. 


\section{Research techniques used}

The main research methods were: the test method, the technical execution assessment method, the mathematical and statistical method, the graphical method.

Motor qualities were tested as follows:

- For strength quality: stall bar pike with legs raising up to the support point - maximum number of repetitions in $30 \mathrm{sec}$., push-up - maximum number of repetitions in $30 \mathrm{sec}$., single-leg squat, the other maintained at $90^{\circ}$ and vertical jump.

- For flexibility quality: right and left sagittal split, side split and bending forward on the gymnastics bench. In the case of split elements, the torso, pelvis and leg positions were assessed by grades.

For statistical processing, the central tendency indicators and the Pearson Coefficient were used to determine correlations between the established variables and their significance.

\section{Results and Discussion}

We present below the statistically processed results, in terms of central tendency indicators and correlations between difficulty elements and performance, for mobility and strength tests.

\section{Statistical indicators - Central tendency}

- Difficulty elements (Table 1)

Table 1. Central tendency of grades for the execution of difficulty elements

\begin{tabular}{lcccc}
\hline \multicolumn{1}{c}{ Statistical indicators } & $\begin{array}{c}\text { Straddle } \\
\text { support }\end{array}$ & Straddle jump & $\begin{array}{c}\text { Illusion to vertical } \\
\text { split }\end{array}$ & $\begin{array}{c}\text { Helicopter to } \\
\text { wenson }\end{array}$ \\
\hline Mean & 6.46 & 6.79 & 6.61 & 6.47 \\
Median & 6.75 & 7.00 & 7.13 & 6.50 \\
Std. deviation & 1.94 & 1.68 & 1.91 & 1.47 \\
Coefficient of variation & $30.1 \%$ & $24.7 \%$ & $28.8 \%$ & $22.7 \%$ \\
Minimum & 2.00 & 2.50 & 2.50 & 4.25 \\
Maximum & 9.00 & 9.25 & 9.00 & 9.00 \\
Range & 7.00 & 6.75 & 6.50 & 4.75 \\
\hline
\end{tabular}

The central tendency of grades for difficulty elements is given by the average values ranging from 6.46 to 6.79 and the median, whose values show the same tendency, the athletes receiving similar grades for the four elements. Grade distribution is relatively homogeneous for all difficulty elements, but, in the case of Straddle support, it is at the borderline between relatively homogeneous and non-homogeneous. This is also reflected by the range, which, for the Straddle-support element, has the highest value, the minimum grade being 2, and the maximum grade, 9. For the next two elements, namely Straddle jump and Illusion to vertical split, grades are similar in variation. For the Helicopter-to-wenson difficulty element, the athletes received closer grades, a claim supported by both the lower coefficient of variation (22.7\%) and the range of 4.75 , the minimum grade being 4.25 , and the maximum grade, 9 .

- Flexibility elements (Table 2)

Table 2. Central tendency indicators for flexibility elements

\begin{tabular}{|c|c|c|c|c|c|}
\hline \multirow{2}{*}{ Statistical indicators } & \multirow{2}{*}{ Right sagittal split } & \multirow{2}{*}{ Left sagittal split } & \multirow{2}{*}{ Side split } & \multicolumn{2}{|c|}{ Stand and reach } \\
\hline & & & & $\mathrm{cm}$ & grade \\
\hline Mean & 8.83 & 8.50 & 9.17 & 6.92 & 7.78 \\
\hline Median & 9.00 & 8.00 & 9.00 & 7.00 & 8.00 \\
\hline
\end{tabular}


International Proceedings of Human Motricity/ ICPESK 2019

Supplementary Issue of Discobolul - Physical Education, Sport and Kinetotherapy Journal, 2019

\begin{tabular}{lccccc} 
Std. deviation & 0.79 & 0.79 & 0.79 & 3.38 & 2.21 \\
Coefficient of variation & $8.9 \%$ & $9.2 \%$ & $8.6 \%$ & $48.9 \%$ & $28.4 \%$ \\
Minimum & 7.00 & 7.00 & 8.00 & 1.50 & 3.00 \\
Maximum & 10.00 & 10.00 & 10.00 & 14.00 & 10.00 \\
Range & 3.00 & 3.00 & 2.00 & 12.50 & 7.00 \\
\hline
\end{tabular}

The central tendency of grades for mobility elements is expressed by the average values, which are between 7.78 and 9.17, and the median, whose values are between 8.00 and 9.00. Grade distribution is homogeneous for all flexibility elements, which is also reflected by the range, whose values are low, especially for split elements.

- Strength elements (Table 3)

Table 3. Central tendency indicators for strength elements

\begin{tabular}{lccccc}
\hline \multirow{2}{*}{ Statistical indicators } & Hanging leg raise in & Push-ups in & Vertical jump & \multicolumn{2}{c}{ Single-leg squat } \\
\cline { 5 - 6 } & $30 "$ & $30 ”$ & $(\mathrm{~cm})$ & left in 30” & right in 30” \\
\hline Mean & 12.33 & 25.06 & 43.06 & 20.17 & 18.83 \\
Median & 14.00 & 23.50 & 43.00 & 20.00 & 19.50 \\
Std. deviation & 5.37 & 3.92 & 4.52 & 3.37 & 3.70 \\
Coefficient of variation & $43.5 \%$ & $15.6 \%$ & $10.5 \%$ & $16.7 \%$ & $19.6 \%$ \\
Minimum & 1.00 & 19.00 & 30.00 & 13.00 & 10.00 \\
Maximum & 19.00 & 32.00 & 49.00 & 26.00 & 25.00 \\
Range & 18.00 & 13.00 & 19.00 & 13.00 & 15.00 \\
\hline
\end{tabular}

As regards the central tendency indicators for strength elements, it is noted that performances in the five subtests are very different, in the sense that, for the pike element on stall bars, the gymnasts have a modest average -12.33 , with a very high variation in the results $-43.5 \%$, while for the standing vertical jump, their average is $43.06 \mathrm{~cm}$, associated with high homogeneity of the results. In the push-up subtest, the average score of 25.06 and the homogeneous distribution of the results, $15.6 \%$, indicate that strength in the arms and shoulder girdle has sufficient reserve to increase, since the values recorded by most athletes are not at the upper bound.

\section{Correlations between technical execution and the results for physical preparation tests}

We present below the summary table of correlations between the technical execution of difficulty elements and the results for elements relating to flexibility and physical preparation (Table 4).

Table 4. Correlation between the execution of technical difficulty elements and flexibility and strength elements

\begin{tabular}{|c|c|c|c|c|c|}
\hline \multirow[b]{2}{*}{ Elements } & \multirow[b]{2}{*}{$\begin{array}{l}\text { Pearson } \\
\text { Correlation }\end{array}$} & \multicolumn{4}{|c|}{ DIFFICULTY ELEMENTS } \\
\hline & & $\begin{array}{l}\text { Straddle } \\
\text { support }\end{array}$ & $\begin{array}{l}\text { Straddle } \\
\text { jump }\end{array}$ & $\begin{array}{l}\text { Illusion to vertical } \\
\text { split }\end{array}$ & $\begin{array}{l}\text { Helicopter } \\
\text { to wenson }\end{array}$ \\
\hline \multicolumn{6}{|c|}{ FLEXIBILITY ELEMENTS } \\
\hline \multirow{2}{*}{ Right sagittal split } & $\mathrm{R}$ & 0.362 & $0.486 *$ & 0.435 & $0.480 *$ \\
\hline & P-value & 0.140 & 0.041 & 0.071 & .044 \\
\hline \multirow{2}{*}{ Left sagittal split } & $\mathrm{R}$ & 0.352 & $0.497 *$ & 0.363 & 0.421 \\
\hline & P-value & 0.152 & 0.036 & 0.139 & 0.082 \\
\hline \multirow{2}{*}{ Side split } & $\mathrm{R}$ & -0.063 & 0.128 & -0.043 & -0.123 \\
\hline & $\mathrm{P}$-value & 0.805 & 0.612 & 0.867 & 0.626 \\
\hline \multirow{2}{*}{ Bench $(\mathrm{cm})$} & $\mathrm{R}$ & 0.110 & 0.310 & 0.065 & 0.327 \\
\hline & P-value & 0.663 & 0.211 & 0.796 & 0.185 \\
\hline \multirow{2}{*}{ Bench (grade) } & $\mathrm{R}$ & -0.115 & -0.283 & -0.064 & -0.315 \\
\hline & P-value & 0.648 & 0.255 & 0.802 & 0.203 \\
\hline
\end{tabular}


International Proceedings of Human Motricity/ ICPESK 2019 Supplementary Issue of Discobolul - Physical Education, Sport and Kinetotherapy Journal, 2019

\begin{tabular}{lccccc} 
& $\mathrm{R}$ & $\mathbf{0 . 5 8 1}$ & $\mathbf{0 . 7 3 7 * *}$ & $\mathbf{0 . 4 7 2} *$ & $\mathbf{0 . 6 0 6}^{* *}$ \\
Stall bar pike & P-value & $\mathbf{0 . 0 1 1}$ & $\mathbf{0 . 0 0 0}$ & $\mathbf{. 0 4 8}$ & $\mathbf{. 0 0 8}$ \\
& $\mathrm{R}$ & $\mathbf{0 . 6 5 4} * *$ & $\mathbf{0 . 6 3 3} * *$ & $\mathbf{0 . 5 7 6}$ & $\mathbf{0 . 5 3 0}$ \\
Push-ups in 30 sec. & P-value & $\mathbf{0 . 0 0 3}$ & $\mathbf{0 . 0 0 5}$ & $\mathbf{0 . 0 1 2}$ & $\mathbf{0 . 0 2 4}$ \\
& $\mathrm{R}$ & 0.032 & 0.120 & -0.247 & 0.062 \\
Vertical jump (cm) & P-value & 0.899 & 0.635 & 0.324 & 0.806 \\
& $\mathrm{R}$ & $\mathbf{0 . 5 8 0 *}$ & 0.429 & 0.286 & 0.376 \\
Right single-leg squat & P-value & $\mathbf{0 . 0 1 2}$ & 0.076 & 0.250 & 0.124 \\
& $\mathrm{R}$ & $\mathbf{0 . 5 5 4}$ & $\mathbf{0 . 5 1 4}$ & 0.255 & 0.313 \\
Left single-leg squat & P-value & $\mathbf{0 . 0 1 7}$ & $\mathbf{0 . 0 2 9}$ & 0.307 & 0.205 \\
\hline
\end{tabular}

*. Correlation is significant at the 0.05 level (2-tailed).

**. Correlation is significant at the 0.01 level (2-tailed).

Straddle support - Correlation with flexibility and strength elements (Table 5)

Table 5. Correlation between the Straddle-support difficulty element and flexibility and strength elements

\begin{tabular}{|c|c|c|c|c|c|c|c|c|c|}
\hline $\begin{array}{c}\text { Pearson } \\
\text { Correlation }\end{array}$ & $\begin{array}{c}\text { Right } \\
\text { sagittal } \\
\text { split }\end{array}$ & $\begin{array}{c}\text { Left } \\
\text { sagittal } \\
\text { Split }\end{array}$ & $\begin{array}{l}\text { Side } \\
\text { split }\end{array}$ & $\begin{array}{l}\text { Bench } \\
(\mathrm{cm})\end{array}$ & $\begin{array}{c}\text { Stall bar } \\
\text { pike in } 30 "\end{array}$ & $\begin{array}{l}\text { Push-ups } \\
\text { in } 30 "\end{array}$ & $\begin{array}{c}\text { Standing } \\
\text { vertical } \\
\text { jump }(\mathrm{cm})\end{array}$ & $\begin{array}{c}\text { Wolf } \\
\text { position on } \\
\text { stall bars - } \\
\text { right in } 30 "\end{array}$ & $\begin{array}{c}\text { Wolf } \\
\text { position on } \\
\text { stall bars - } \\
\text { left in } 30 "\end{array}$ \\
\hline $\mathrm{R}$ & 0.362 & 0.352 & -0.063 & 0.110 & 0.581 & 0.654 & 0.032 & 0.580 & 0.554 \\
\hline $\mathrm{P}$ & 0.140 & 0.152 & 0.805 & 0.663 & 0.011 & 0.003 & 0.899 & 0.012 & 0.017 \\
\hline \multirow[t]{2}{*}{$\begin{array}{l}\text { Correlation } \\
\text { type }\end{array}$} & Pos. & Pos. & Neg. & Pos. & Pos. & Pos. & Pos. & Pos. & Pos. \\
\hline & 0.131 & 0.124 & 0.004 & 0.012 & 0.338 & 0.428 & 0.001 & 0.336 & 0.307 \\
\hline $\begin{array}{l}\text { Correlation } \\
\text { intensity }\left(r^{2}\right)\end{array}$ & $\begin{array}{l}\text { medium } \\
\text { to large }\end{array}$ & $\begin{array}{l}\text { small to } \\
\text { medium }\end{array}$ & small & small & $\begin{array}{c}\text { large to } \\
\text { very large }\end{array}$ & $\begin{array}{c}\text { large to } \\
\text { very large }\end{array}$ & small & $\begin{array}{l}\text { large to very } \\
\text { large }\end{array}$ & $\begin{array}{c}\text { large to } \\
\text { very large }\end{array}$ \\
\hline
\end{tabular}
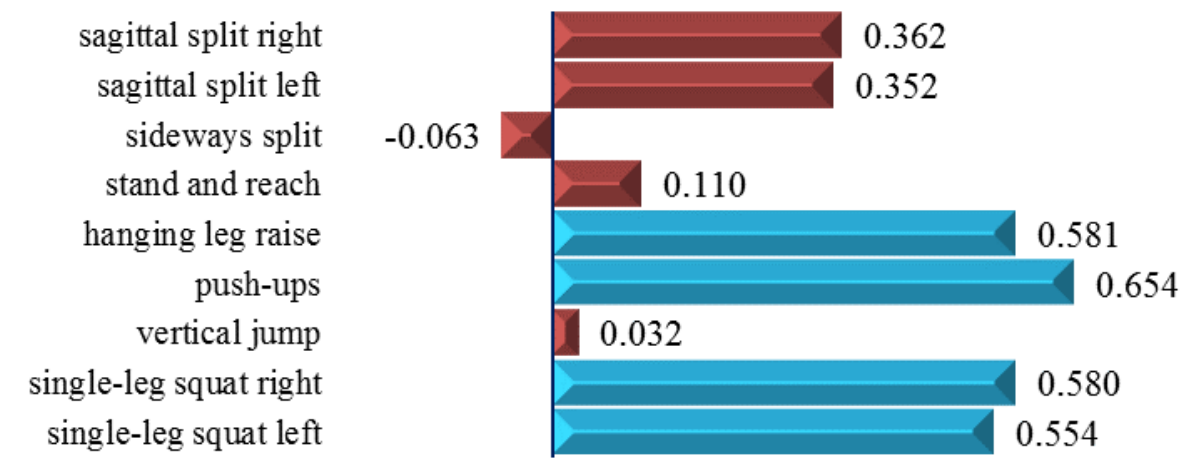

\section{Significant correlation}

Insignificant correlation

Figure 1. Graphical representation of correlations between the execution of Straddle-support element and the results for mobility and strength tests

The Straddle-support difficulty element correlates positively and statistically significantly (p < 0.05$)$ with strength elements: Stall bar pike in 30", Push-ups in 30", Single-leg squat (to both the right and left sides). Between Straddle support and these strength elements, the intensity (effect size) is large to very large. The Straddle-support element correlates, at medium to high intensity, with the right sagittal split element, and, at low to medium intensity, with the left sagittal split element. For the side split, bench and standing vertical jump, the 
correlation intensity is low, so the correlation is negligible. The correlation coefficients between Straddle support and the results for mobility and strength elements are graphically shown in Figure 1.

Straddle jump - Correlation with flexibility and strength elements (Table 6)

Table 6. Correlation between the Straddle-jump difficulty element and flexibility and strength elements

\begin{tabular}{|c|c|c|c|c|c|c|c|c|c|}
\hline $\begin{array}{c}\text { Pearson } \\
\text { Correlation }\end{array}$ & $\begin{array}{c}\text { Right } \\
\text { sagittal } \\
\text { split } \\
\end{array}$ & $\begin{array}{c}\text { Left } \\
\text { sagittal } \\
\text { split } \\
\end{array}$ & $\begin{array}{l}\text { Side } \\
\text { split }\end{array}$ & $\begin{array}{l}\text { Stand and } \\
\text { reach } \\
(\mathrm{cm})\end{array}$ & $\begin{array}{l}\text { Hanging } \\
\text { leg raise } \\
\text { in } 30 "\end{array}$ & $\begin{array}{l}\text { Push-ups } \\
\text { in 30" }\end{array}$ & $\begin{array}{l}\text { Vertical } \\
\text { jump } \\
(\mathrm{cm})\end{array}$ & $\begin{array}{l}\text { Single-leg } \\
\text { squat - } \\
\text { right in } 30 "\end{array}$ & $\begin{array}{c}\text { Single-leg } \\
\text { squat - } \\
\text { left in } 30 "\end{array}$ \\
\hline $\mathrm{R}$ & 0.486 & 0.497 & 0.128 & 0.310 & 0.737 & 0.633 & 0.120 & 0.429 & 0.514 \\
\hline $\mathrm{P}$ & 0.041 & 0.036 & 0.612 & 0.211 & $<0.001$ & 0.005 & 0.635 & 0.076 & 0.029 \\
\hline \multirow[t]{2}{*}{$\begin{array}{l}\text { Correlation } \\
\text { type }\end{array}$} & Pos. & Pos. & Pos. & Pos. & Pos. & Pos. & Pos. & Pos. & Pos. \\
\hline & 0.236 & 0.247 & 0.016 & 0.096 & 0.543 & 0.401 & 0.014 & 0.184 & 0.264 \\
\hline $\begin{array}{c}\text { Correlation } \\
\text { intensity }\left(\mathrm{r}^{2}\right)\end{array}$ & $\begin{array}{l}\text { medium } \\
\text { to large }\end{array}$ & $\begin{array}{l}\text { medium } \\
\text { to large }\end{array}$ & small & $\begin{array}{l}\text { small to } \\
\text { medium }\end{array}$ & $\begin{array}{l}\text { large to } \\
\text { very large }\end{array}$ & $\begin{array}{l}\text { large to } \\
\text { very large }\end{array}$ & small & $\begin{array}{c}\text { medium to } \\
\text { large }\end{array}$ & $\begin{array}{l}\text { large to } \\
\text { very large }\end{array}$ \\
\hline
\end{tabular}

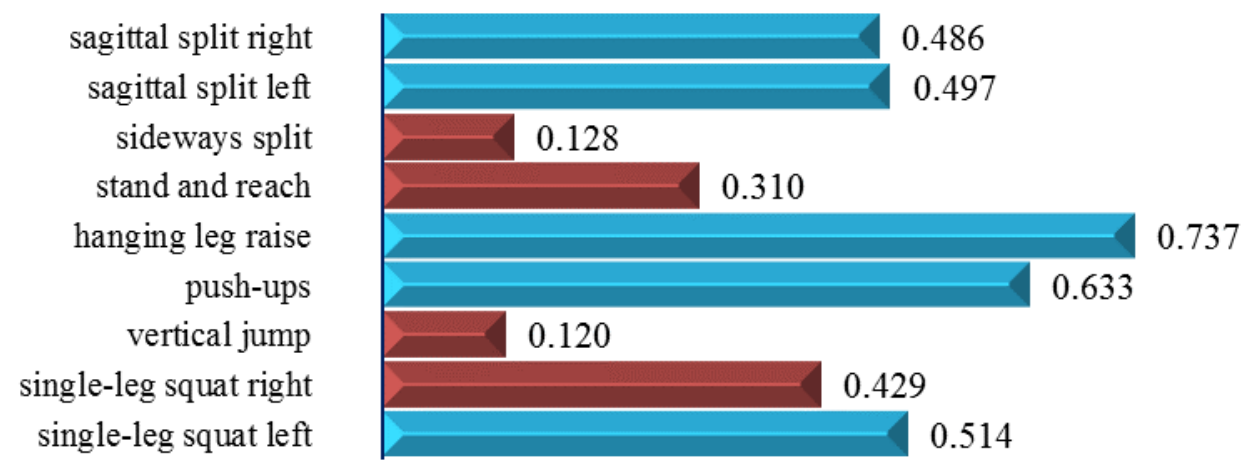

Figure 2. Graphical representation of correlations between the execution of Straddle-jump element and the results for flexibility and strength tests

The Straddle-jump difficulty element correlates positively and statistically significantly $(\mathrm{p}<0.05)$ with the following elements: right sagittal split, left sagittal split, pike, push-ups and left single-leg squat. Between Straddle jump and these strength elements, the correlation intensity is medium to large (for sagittal split) and large to very large (for the pike, push-ups and left single-leg squat). The correlation coefficients between Straddle jump and the results for mobility and strength elements are graphically shown in Figure 2.

Illusion to vertical split - Correlation with flexibility and strength elements (Table 7)

Table 7. Correlation between the Illusion-to-vertical-split difficulty element and flexibility and strength elements

\begin{tabular}{cccccccccc}
\hline $\begin{array}{c}\text { Pearson } \\
\text { Correlation }\end{array}$ & $\begin{array}{c}\text { Right } \\
\text { sagittal } \\
\text { split }\end{array}$ & $\begin{array}{c}\text { Left } \\
\text { sagittal } \\
\text { split }\end{array}$ & $\begin{array}{c}\text { Side } \\
\text { split }\end{array}$ & $\begin{array}{c}\text { Bench } \\
(\mathrm{cm})\end{array}$ & $\begin{array}{c}\text { Stall bar } \\
\text { pike in } \\
30 ”\end{array}$ & $\begin{array}{c}\text { Push-ups } \\
\text { in 30” }\end{array}$ & $\begin{array}{c}\text { Standing } \\
\text { vertical } \\
\text { jump (cm) }\end{array}$ & $\begin{array}{c}\text { Wolf } \\
\text { position on } \\
\text { stall bars - } \\
\text { right in 30" }\end{array}$ & $\begin{array}{c}\text { Wolf } \\
\text { position on } \\
\text { stall bars - } \\
\text { left in 30" }\end{array}$ \\
\hline $\mathrm{R}$ & 0.435 & 0.363 & -0.043 & 0.065 & $\mathbf{0 . 4 7 2}$ & $\mathbf{0 . 5 7 6}$ & -0.247 & 0.286 & 0.255 \\
$\mathrm{P}$ & 0.071 & 0.139 & 0.867 & 0.796 & $\mathbf{0 . 0 4 8}$ & $\mathbf{0 . 0 1 2}$ & 0.324 & 0.250 & 0.307 \\
$\begin{array}{c}\text { Correlation } \\
\text { type }\end{array}$ & Pos. & Pos. & Neg. & Pos. & Pos. & Pos. & Neg. & Pos. & Pos. \\
$\begin{array}{c}\text { Correlation } \\
\text { P. }\end{array}$ & 0.189 & 0.132 & 0.002 & 0.004 & 0.223 & 0.332 & 0.061 & 0.082 & 0.065
\end{tabular}


International Proceedings of Human Motricity/ ICPESK 2019

Supplementary Issue of Discobolul - Physical Education, Sport and Kinetotherapy Journal, 2019

intensity $\left(r^{2}\right)$

\begin{tabular}{|c|c|c|c|c|c|c|c|c|}
\hline $\begin{array}{l}\text { medium } \\
\text { to large }\end{array}$ & $\begin{array}{l}\text { medium } \\
\text { to large }\end{array}$ & small & small & $\begin{array}{l}\text { medium } \\
\text { to large }\end{array}$ & $\begin{array}{c}\text { large to } \\
\text { very large }\end{array}$ & $\begin{array}{l}\text { small to } \\
\text { medium }\end{array}$ & $\begin{array}{l}\text { small to } \\
\text { medium }\end{array}$ & $\begin{array}{l}\text { small to } \\
\text { medium }\end{array}$ \\
\hline
\end{tabular}

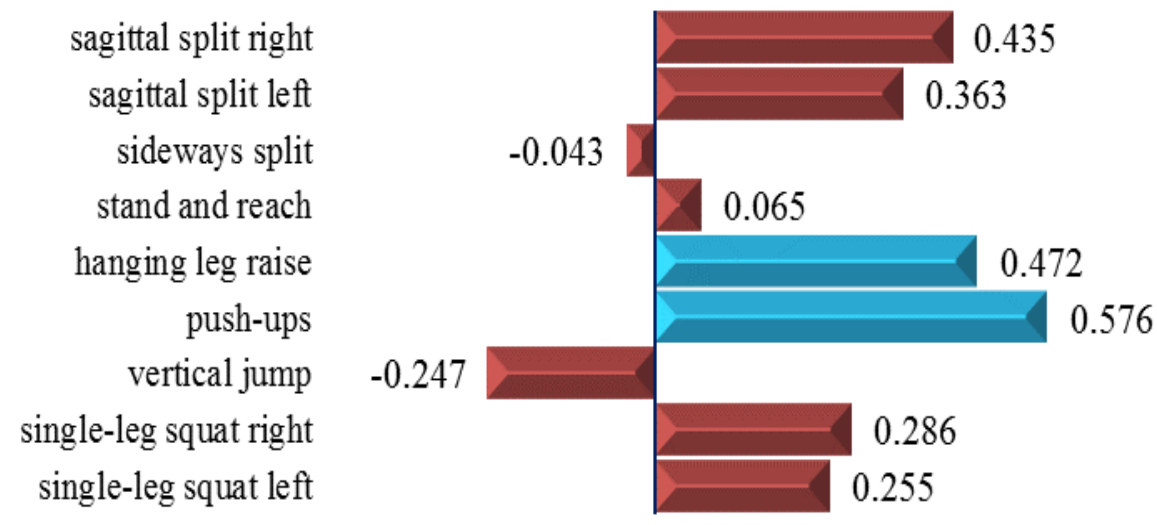

Figure 3. Graphical representation of correlations between the execution of Illusion-to-vertical-split element and the results for flexibility and strength tests

The Illusion-to-vertical-split difficulty element correlates positively and statistically significantly $(\mathrm{p}<0.05)$ with the pike and push-up strength elements. Between Illusion to vertical split and these strength elements, the correlation intensity is medium to large (for the pike) and large to very large (for push-ups). The correlation coefficients between Illusion to vertical split and the results for flexibility and strength elements are graphically shown in Figure 3.

Helicopter to wenson - Correlation with mobility and strength elements (Table 8)

Table 8. Correlation between the Helicopter-to-wenson difficulty element and mobility and strength elements

\begin{tabular}{|c|c|c|c|c|c|c|c|c|c|}
\hline $\begin{array}{c}\text { Pearson } \\
\text { Correlation }\end{array}$ & $\begin{array}{l}\text { Right } \\
\text { sagittal } \\
\text { split }\end{array}$ & $\begin{array}{c}\text { Left } \\
\text { sagittal } \\
\text { split }\end{array}$ & $\begin{array}{l}\text { Side } \\
\text { split }\end{array}$ & $\begin{array}{l}\text { Bench } \\
(\mathrm{cm})\end{array}$ & $\begin{array}{c}\text { Stall bar } \\
\text { pike in } \\
30 "\end{array}$ & $\begin{array}{l}\text { Push-ups } \\
\text { in } 30 "\end{array}$ & $\begin{array}{c}\text { Standing } \\
\text { vertical } \\
\text { jump }(\mathrm{cm})\end{array}$ & $\begin{array}{c}\text { Wolf } \\
\text { position on } \\
\text { stall bars - } \\
\text { right in } 30 "\end{array}$ & $\begin{array}{c}\text { Wolf } \\
\text { position on } \\
\text { stall bars - } \\
\text { left in } 30 "\end{array}$ \\
\hline $\mathrm{R}$ & 0.480 & 0.421 & -0.123 & 0.327 & 0.606 & 0.530 & 0.062 & 0.376 & 0.313 \\
\hline $\mathrm{P}$ & 0.044 & 0.082 & 0.626 & 0.185 & 0.008 & 0.024 & 0.806 & 0.124 & 0.205 \\
\hline \multirow[t]{2}{*}{$\begin{array}{l}\text { Correlation } \\
\text { type }\end{array}$} & Pos. & Pos. & Neg. & Pos. & Pos. & Pos. & Pos. & Pos. & Pos. \\
\hline & 0.230 & 0.177 & 0.015 & 0.107 & 0.367 & 0.281 & 0.004 & 0.142 & 0.098 \\
\hline $\begin{array}{l}\text { Correlation } \\
\text { intensity }\left(r^{2}\right)\end{array}$ & $\begin{array}{l}\text { medium } \\
\text { to large }\end{array}$ & $\begin{array}{l}\text { medium } \\
\text { to large }\end{array}$ & small & $\begin{array}{l}\text { small to } \\
\text { medium }\end{array}$ & $\begin{array}{l}\text { large to } \\
\text { very large }\end{array}$ & $\begin{array}{l}\text { large to } \\
\text { very large }\end{array}$ & small & $\begin{array}{c}\text { medium to } \\
\text { large }\end{array}$ & $\begin{array}{l}\text { small to } \\
\text { medium }\end{array}$ \\
\hline
\end{tabular}
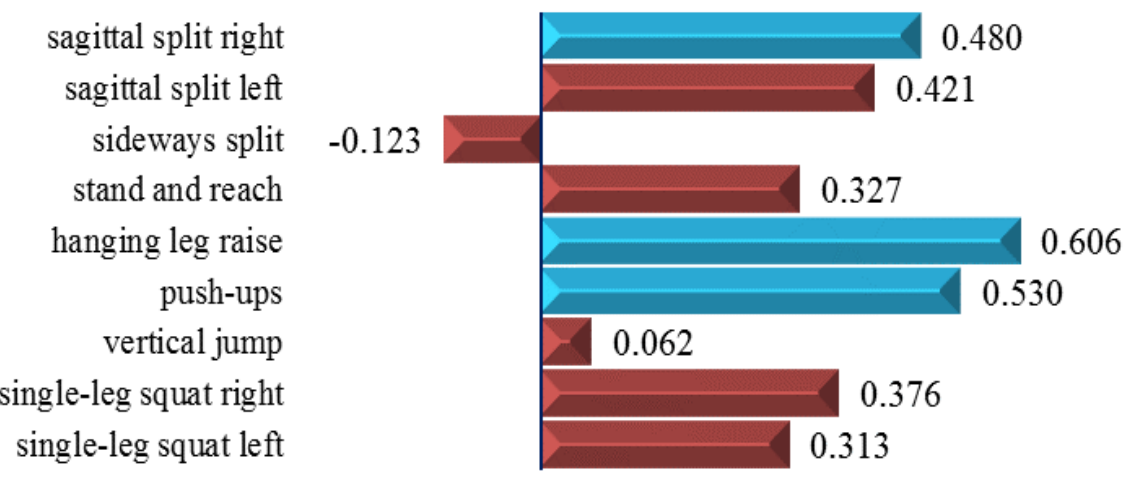

Figure 4. Graphical representation of correlations between the execution of Helicopter-to-wenson element and the results for mobility and strength tests 
The Helicopter-to-wenson difficulty element correlates positively and statistically significantly $(\mathrm{p}<0.05)$ with the elements: right sagittal split, pike and push-ups. Between the execution of Helicopter-to-wenson element and the test results, the correlation intensity is medium to large (for the right sagittal split) and large to very large (for the pike and push-ups). The correlation coefficients between Helicopter to wenson and the results for physical preparation tests are graphically shown in Figure 4.

\section{Conclusion}

Concerning the execution of difficulty elements, the group of athletes recorded average scores corresponding to the satisfactory scale. The group is relatively homogeneous in the execution of Straddle jump, Illusion to vertical split and Helicopter to wenson and non-homogeneous (at the limit) in the execution of Straddle support.

As regards flexibility elements, the tested gymnasts recorded average scores corresponding to the good to very good scale, and the coefficient of variation indicated good homogeneity of the group of athletes.

With reference to strength elements, it can be stated that the group generally recorded satisfactory scores in the pike test, with effects on the long-term physical preparation objectives. Except for the pike test, where the group was non-homogeneous, the other results indicated its relative homogeneity.

Statistical interpretation of the correlation coefficients has led to the validation of most tests in relation to difficulty elements: Straddle support correlates statistically significantly with the results for the pike, push-ups and right-left single-leg squats; Straddle jump correlates statistically significantly with the right-left sagittal split, pike, push-ups and left single-leg squat; Illusion to vertical split correlates statistically significantly with the pike and push-ups; Helicopter correlates positively and statistically significantly with the right sagittal split, pike and pushups. Although most of the other correlations are positive, their intensity is different at $p=\geq 005$. A possible explanation is the size of the tested sample, under the conditions of a decreased selection base in recent years.

The data obtained in this paper represent a starting point for the creation of a database aimed to systematically record the physical preparation test results achieved by junior age categories. Thus, the federation technicians can establish scales to test relevant motor qualities for the execution of technical difficulty elements and can adjust the tests according to the evolution of athletes.

\section{Author's Contributions}

All authors contributed equally to this study and should be considered as main authors.

\section{References}

Aleksandraviciene, R., Zaicenkoviene, K., Stasiule, L., \& Stasiulis, A. (2015). Physiological responses and energetics of competitive group exercise in female aerobic gymnastics with different levels of performance. Perceptual and Motor Skills, 120(3), 787-803. https://doi.org/10.2466/29.26.PMS.120v15x7

Alves, C. R. R., Borelli, M. T. C., De Salles Paineli, S., de Almeida Azevedo, R., GomesBorelli, C. C., Lancha Junior, A.H., ... Artioli, G. G. (2015). Development of a specific anaerobic field test for aerobic gymnastics. PloS ONE, 10(4). https://doi.org/10.1371/journal.pone.0123115

Bota, A., \& Urzeală, C. (2013). Correlative aspects regarding functional stress and neuromuscular control in high performance aerobic gymnastics - Individual event. In Procedia - Social and Behavioral Sciences, 93 (pp. 2090-2094). https://doi.org/10.1016/j.sbspro.2013.10.171

Lijuan, G. (2013). A study on the change tendency of difficulty elements in aerobic gymnastics competitions under the new rules. Journal of Chemical and Pharmaceutical Research, 5(12), 750-756. Retrieved from http://www.jocpr.com/articles/a-study-on-the-change-tendency-of-difficulty-elements-in-aerobic-gymnasticscompetitions-under-the-new-rules.pdf

Raiola, G., Giugno, I., Scassillo, I., \& Di Tore, P. A. (2013). An experimental study on aerobic gymnastics: Performance analysis as an effective evaluation for technique and teaching of motor gestures. Journal of Human Sport and Exercise, 8(2), 297-306. http://dx.doi.org/10.4100/jhse.2012.8.Proc2.32

Rieder, H. (1987). Mejorar la técnica [Improving the technique]. Entrenamiento Deportivo, 1(1), 47-56.

Seirul-Io Vargas, F. (1987). Technique and its training. Apunts Medicina de l'Esport, 24(93), 189-199. Retrieved from http://www.entrenamientodeportivo.org/articulos/art-techniquetrainingseirul-lo.htm 
International Proceedings of Human Motricity/ ICPESK 2019

Supplementary Issue of Discobolul - Physical Education, Sport and Kinetotherapy Journal, 2019

Sergiev, G. (2004). Sports aerobics technique of execution and training methods of difficulty elements. Sofia: Bolid INS.

Xiao-Ying, Z., \& Huang, L. (2008). An analysis on difficult movement in men's individual event in the $9^{\text {th }}$ World Sports Aerobics Championships. Journal of Beijing Sport University, 11. Retrieved from http://en.cnki.com.cn/Article_en/CJFDTOTAL-BJTD200811040.htm 